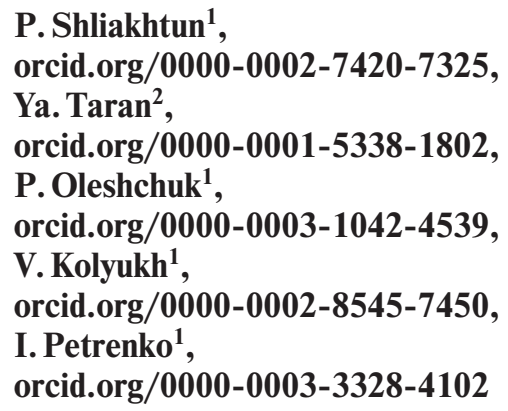

1 - Taras Shevchenko National University of Taras Shevchenko National University of Kyiv, Kyiv, Ukraine, e-mail: politnauk@ukr.net

2 - Taras Shevchenko National University "Chernihiv Collegium”, Chernihiv, Ukraine

\title{
RISK MANAGEMENT: APPROACHES AND FIELDS OF APPLICATION
}

Purpose. To reveal modern approaches to political risk management in the countries with economies in transition.

Methodology. The authors used the system-structural, structural-functional methods, as well as the methods of comparison, analysis, synthesis and expert evaluation.

Findings. The authors reviewed modern approaches to risk management and identified three global forces that determine political risks and their management:

1. Dramatic political changes after the end of the Cold War.

2. Innovation in supply chains.

3. Technical revolution.

Based on the materials reviewed, the authors developed a sequence of political risk management in the countries with economies in transition.

Originality. A sequence of political risk management in the countries with economies in transition has been developed on the basis of studying the features of their unstable socio-political situation, as well as global forces that determine political risks and their management.

Practical value. The use of the results obtained in the study on the peculiarities of risk management in countries with economies in transition allows identifying the opportunities of the process of minimizing the negative consequences of political risks and preventing them for the countries in transition, including those for increasing their investment attractiveness from foreign countries and international organizations.

Keywords: political risk management, decision making, countries with economies in transition

Introduction. In recent decades, the risk management process has become an object of extensive research in the scientific community, and the course of Risk Management has gained particular popularity in classical universities of the European Union [1]. The main reason for close attention to this problem is the need of the society for certain management skills that allow building effective organizational and behavioral models in conditions of increased uncertainty and risks escalation.

Risk management as a set of certain professional qualities and actions is a must in modern organizational models. It allows managing the organization in the face of potential risks and uncertainties.

The research on risk management as well as proposals that improve the efficiency of risk management is of particular importance for Ukraine. Ukraine belongs to the states with economies in transition. This involves radical restructuring of the functions of the state and state institutions, which are changing from a centralized planned economy to a market economy. The formation of new market institutions as well as economic liberalization increases political, economic and social risks. In the proposed article, the authors will consider modern approaches to risk management. The research will focus on the use of the considered approaches in public administration. The authors investigate the peculiarities of political risk management in the countries with economies in transition.

Results. Risk management is currently understood as a process of making and implementing specific management decisions. The process of "risk management" can be defined as follows. It involves the risk identification and assessment with the aim of subsequent coordinated and economical use of available resources to maximize the implementation of available opportunities in conditions of minimization, monitoring

(c) Shliakhtun P., Taran Ya., Oleshchuk P., Kolyukh V., Petrenko I., 2020 and control of the feasible (or real) impact of adverse events [1].

Risks can come from a variety of sources, including political, economic, social, environmental, and other ones. Major risk management standards are being developed at the global, regional and national levels. Depending on the degree of the state influence in the world arena, it is allowed to promote national risk management standards in neighboring countries, as well as in other countries of the world. Each of the above levels offers its own approaches and rewards in risk management. The process of risk management is prescribed in the rules, instructions, decrees, laws, which provide for individual and organizational actions aimed at reducing risks, as well as their preventing.

Consider some examples. In 1969, a global non-profit professional organization specialized in the creation and management of projects was founded. It is called The Project Management Institute (PMI). During its existence, the PMI has clarified its specialization several times. At present, it is declared as "the development of global standards of lean thinking in Project Management" [2].

The Project Management Institute develops and promotes a risk management approach called the "project approach". The essence of the project approach is conveyed by the slogan "projection of actions from the present into the future" [2]. The project approach offered by The Project Management Institute is based on understanding that any project (political, economic, social, scientific, and so on) primarily involves creating value for an organization in the flow of time. It is assumed that a project should aim to create or improve the value system of the organization and its customers, thereby creating value for all interested parties of the organization. The project approach is the development of a sequence of actions to create value for the system or the global value of the organization, which in turn generates values for customers, employees, owners, partners and society. 
Project management is the practice of managing the streams of creating the project values in order to maximize its net benefit. Thus, the project approach provides for risk management based on the created and actualized organization values. The reward in this approach is the maximum net benefit to the organization.

The risk management standards that are being developed by The Project Management Institute have reached the global level, having proven their effectiveness in creating projects in the USA, Japan, Germany, Singapore and other countries that are currently the world's economic leaders. The project approach creates the cult of the organization and organization value standards. The reward is the organization authority and the growth of personal authority in the organization, which is supported by the material factor [3].

The next example is The National Institute of Standards and Technology (NIST). The institute was founded in 1901 as the US National Bureau of Standards. It is currently a US government laboratory, the director of which is also the US Undersecretary of Commerce for Standards and Technology. In 2018 , the annual turnover of the Institute exceeded $\$ 1.2$ billion [4]. The main mission of The National Institute of Standards and Technology is to promote innovation and enhance the competitiveness of US industry in global sustainable development. It was this mission that took the Institute of the US Department of Commerce beyond the regional and even national level. The standards adopted by the Institute are used in many countries of the world, which are subject to the political influence of the United States.

The National Institute of Standards and Technology currently consists of six laboratories and seven standing committees. Three committees specialize in developing risk management standards:

1. Advisory Committee on Earthquake Hazards Reduction (ACEHR).

2. National Construction Safety Team Advisory Committee (NCST Advisory Committee).

3. Information Security and Privacy Advisory Board (ISPAB).

The National Institute of Standards and Technology (NIST) has had a real impact on US innovation and quality of life, as well as strengthening US leadership in the global world order. Laura Ost in the article "NIST's Real Impact on Innovation and Quality of Life" revealed the scale of the real influence of this state institution on the promotion and consolidation of national ideas at the global level in specific standards [5].

The main approach promoted by The National Institute of Standards and Technology (NIST) is interpreted as "measurements are the main key to scientific and technological innovation" [5]. The reward of this approach is the significant impact of risk management standards on American innovation and quality of life. "More accurate measurements always find useful applications" [5].

It is noteworthy that it was The National Institute of Standards and Technology (NIST) that has developed and now widely promotes the risk management standards in the following areas:

a) restoring the ozone layer in the Earth's atmosphere and combating climate change;

b) improving public health and safety;

c) planning and responding to emergencies;

d) the impact of science on improving preparedness and response to natural disasters;

e) forensic medicine;

f) cybersecurity, protecting national infrastructure such as banking and energy supply, as well as the state political foundations;

g) economic development and banking.

Every dollar invested in The National Institute of Standards and Technology brought in 1976 dollars of profit to the US government [5].
The third example. One of the approaches to successful risk management involves think tanks created on a temporary or permanent basis [6]. The main feature of this approach is unifying specialists for the purpose of effective risk management and prevention. In the area of risk management, think tanks operate on a temporary basis. The benefit of this approach is that any organization that pays for the creation of think tanks eventually gets at its disposal the best specialists who prescribe instructions and recommendations for risk management.

Thus, the risk management process is enshrined in different standards. These standards are driven by approaches to risk management. The risk management process consists of a specific set of activities. In the process of risk management, there are usually four main stages [1]:

1. Establishing context.

2. Identifying potential risks.

3. Assessing risks in terms of their potential impact severity and occurrence.

4. Taking possible measures to reduce the risks.

We can characterize the risk management process as:

a) creating the organization (project) values;

b) considering the risks as an integral part of the organization evolution and organizational processes;

c) involving members of the organization in decisionmaking, including decisions on risk management;

d) admitting the need to refer to uncertainties and assumptions;

e) focusing on systematization and structuring of the organization (project);

f) using up-to-date quality information;

g) developing dynamism, adaptability and flexibility of the organization (project);

h) considering human factors;

i) emphasizing transparency and inclusiveness;

j) organizational agility and responses to changes;

k) capacity for continual improvement and objective reassessment.

Risk management approaches fall into four categories:

1. Risk avoidance.

2. Risk optimization (reduction).

3. Risk insurance or risk sharing among stakeholders.

4. Retention of risks and their consequences by the organization capabilities.

Risk management approaches can fall into one or more categories. In the English-language literature, the categories of risk management are called ACAT categories: avoid, control, accept, or transfer.

Consider a brief description of each of the listed categories.

1 . The first category is called "risk avoidance". This category combines risk management approaches that provide for the refusal of actions that endangers the newly created project (organization). For example, V. Fatkhutdinov examines management approaches that were used to avoid risks when creating a pension fund in Ukraine after the collapse of the USSR. The main approach was a preventive approach, preventing any actions that contained a potential threat to the newly created state structure [7]. Risk management approaches, which are grouped in the first category, provide for the avoidance of all risks, including positive risks that can bring potential benefits to the organization. The reward of these approaches is the sustainable development of the organization.

2. The category of "risk optimization" combines approaches to risk management, which, firstly, systematize risks into negative and positive. Secondly, there are risk management approaches that recommend the use of positive risks to increase the benefit to the organization. For example, I. Kostenko examines the risks of the rapid development of the space industry. Specifically, they manifest themselves in gaps and unclarity in space law. Kostenko notes that space law is a relatively new branch of public international law. Its main task 
is to find a balance between mankind's free access to space and the possibility of establishing ownership of certain research objects in outer space [8]. Therefore, risk management in the space industry is based on the approaches that consider such risks as positive risks (even the risks that are associated with danger to the lives of astronauts). These risk management approaches prescribe the standards (rules, instructions, decrees, laws) which help seek the balance between negative risk and the benefits of space exploration activities. An admissible and reasoned balance is suggested between potential benefits and potential losses. By effectively applying health and safety management standards, etc., the space industry as a specific organization (project) is trying to achieve acceptable levels of residual risk. The main reward of all risk management approaches combined in the second category is the obvious benefit to the organization (project).

3 . The third category brings together various risk management approaches that involve transferring risk management to a third party. The term 'risk transfer' has different meanings. R. Burke and I. Demirag investigated the peculiarities of using stakeholder theory in risk management strategies [9]. As the authors of the study emphasize, the main feature of the risk management approaches combined in the third category can be described as follows. In practice, transferring risk to a third party through insurance or outsourcing, or transferring the ability to manage risk to a third party, does not absolve the first party from risk. The reward of risk management approaches combined in the third category is full or partial compensation for the losses of the first party after the risk event. Technically, risk management by groups (stakeholders) retains risk for the group as a whole. However, the distribution of the consequences of a risk event occurs among all members of the group, which leads to a significant reduction in the impact of risk on the organization (project) as a whole.

4. The last category combines risk management approaches that provide for self-insurance of the organization (project) under conditions of increased risk and uncertainty. For example, A. Prykhodko and V. Oksin investigate corruption as a destabilizing element of the space industry. Corruption as a risk factor involves accepting loss or gain. Losses from corruption in the space industry in some cases are insignificant; therefore they are covered by the funds of the space industry as an organization (project) [10]. All risks that could not be avoided or transferred are retained by default and are overcome by the organization on its own using internal reserves.

Thus, we have considered modern approaches to risk management, which are summarized in four categories. We use the considered theoretical basis for researching the specifics of political risk management in countries with economies in transition. This problem is relevant for Ukraine for two reasons:

1. There have been changes in the development of strategic partnerships. Instead of integration to the East, Ukraine has legislatively consolidated its strategic partnership with Western Europe. The course has been set for the European Union integration [11].

2. It became necessary to form a new political elite capable of managing risks in a country during the period of its transition [12].

Political risk is a type of risk that investors, corporations and governments face, since political decisions and risk events can significantly affect the profit or the expected value of the organization (project) that is being created.

Political risks, as well as the skills to manage them, are an important part of public administration [13]. However, if until recently political risks were considered the most predictable and manageable, now the situation has changed dramatically. C. Rice and A. Zegart argue that at present a significant part of political risks within the countries and between them does not come from governments and state leaders, whose thinking and actions are quite predictable and fit into a logical sequence of actions. Political risks began to come from other players [14]:

a) people with mobile phones capable of filming a video of a minor event and using social media to enforce it on a regional and national scale;

b) minor officials who issue city decrees that, by their actions, can cause negativity to the authorities and lead to regional and national upheavals;

c) terrorists capable of intimidating society and creating the appearance of the "weak" government incapable of ensuring the safety of its citizens;

d) UN officials deciding on and administering sanctions;

e) journalists capable of creating and disseminating fakes that change the domestic and foreign policy of the state.

In fact, in the $21^{s t}$ century, political risks have ceased to be associated with the actions of the legislative and executive state authorities. Political risks have gone beyond the boundaries of the state capitals, offices of political parties, government agencies, etc. Political risks began to be called political actions, the generators of which can be people and events completely far from politics. For example, the COVID-19 pandemic has forced to rethink the foundations of human freedom in postepidemic social reality [15].

Currently, political risk is determined by three global forces [14]:

1. Dramatic changes in policy after the end of the Cold War.

2. Innovations in supply chains.

3. Technical revolution.

Consider the options for managing three global forces that pose political risks in the countries with economies in transition.

First, after the collapse of the USSR, the previously clearly visible borders between adversaries and allies were destroyed. The modern geopolitical landscape is more complex, uncertain and prone to temporary and short-lived alliances. It is for this reason that economic security has gone beyond the boundaries of the relevant ministry, the narrow interests of state and private corporations. It began to be viewed as state security and based on the policy of state and regional security. For example, D. Svyrydenko and O. Stovpets studied the peculiarities of the cultural and economic strategy of modern China. The key initiative of this strategy is the cooperation of Chinese entrepreneurs and highly developed technology enterprises in Europe [16]. However, the events unfolding around the sale of the Motor Sich enterprise in Ukraine have opened a completely new page in understanding political risks and managing them.

Motor Sich is a Ukrainian enterprise that develops, manufactures, repairs and maintains aircraft gas turbine engines for airplanes and helicopters. Also, the enterprise manufactures industrial gas turbine power plant. The enterprise was created in the Russian Empire, in 1907, and until recently Russia was its main partner. After 2014, it lost its Russian sales market and began looking for new partners. Its products did not meet European Union standards, so the management of the enterprise accepted an offer to partner with Beijing Skyrizon Aviation Industry Investment $\mathrm{Co}$, a large investment company from China.

The purchase of the major share of stock in Motor Sich by a Chinese investor led to a political crisis between Ukraine and the United States. The US media presented a bankrupt enterprise that developed and manufactured products that did not meet NATO standards contributed by Elon Musk's innovative enterprises. The press made loud statements by US political leaders who warned the political leadership of Ukraine about the need to cancel the deal. However, two main difficulties arose. First, the deal took place in 2017, 
while the US raised the issue in 2019. Second, the Chinese company had already invested over $\$ 100$ million in the enterprise.

The analysis of the current political crisis as well as the use of political risk management approaches allows us to draw the following conclusions.

1. When selling Motor Sich to the Chinese company Beijing Skyrizon Aviation Industry Investment Co, modern risk management approaches were not used. In particular, during his election campaign in 2016, Donald Trump announced a review of relations with China. In January 2017, after being elected to the post of President of the United States, Trump, in his first decrees, began to limit China's influence on the states that fell within the scope of US interests. Ukraine turned out to be such a country. Therefore, political risk management had to anticipate the US reaction to the sale of a strategic military enterprise to a Chinese investor.

2. Currently, Ukraine is going through the stage of risk optimization from the sale of Motor Sich. On the one hand, the sale of the enterprise according to the laws of Ukraine and international law is an established fact for the Ukrainian government, as well as the real investment of more than $\$ 100$ million into the enterprise, along with the upcoming litigation with a foreign investor in case of the transaction cancellation with a priori losing result and significant amounts of penal sanctions. On the other hand, there is growing political pressure from the United States and, more recently, from European partners, who insist on cancelling the deal.

3. In this situation, we see that the Ukrainian political leadership is trying to share the political risk between the parties concerned. Oleksandr Yaroslavskyi, the owner of the influential DCH group in Ukraine, was involved in the deal. One of the group's activities is the protection of investments of foreign partners: BNP Paribas, American corporations Citigroup and Apollo, as well as Chinese investors, joined by Beijing Skyrizon since August 2020.

4. The authority of Yaroslavskyi and the DCH group, as well as the events over the past few months, indicates that the political leadership of Ukraine has chosen a direction to retain this political risk. This is evidenced by the decree on the temporary abolition of visas for tourists from the PRC, signed by President Zelensky. The decree is valid from August 1, 2020 to January 31, 2021. Its goal is to strengthen friendly relations between Ukraine and China. Also, in August 2020, DCH of Yaroslavskyi and Beijing Skyrizon Aviation Industry Investment Co applied to the Antimonopoly Committee of Ukraine for the purchase of Motor Sich shares. It is now not about Chinese investments, but about Ukrainian-Chinese investments, which, according to the Ukrainian authorities, will significantly reduce the consequences of this political risk.

The considered case is one of the numerous examples that reveal how unpredictable political risks have become and, accordingly, how difficult it has become to manage them.

The second global force that determines contemporary political risks and influences their management is innovation in supply chains. The process of globalization makes the concept of "border" between states conditional. Nowadays, even small businesses can reap the benefits of low offshore wages, lower shipping costs and better inventory management. Many states have created the so-called "free trade zones", which allow investors and entrepreneurs to view the territories of foreign states and workers of enterprises as "expanding their own production" [17].

However, innovative supply chains have a downside. They make companies more vulnerable to disruption in remote locations. Along with expanding companies' relationships with overseas suppliers in search of increased project profit margins, the likelihood that political action will disrupt the distribution of goods and services to their customers increases. Any domestic policy decision that affects the supply channels and the speed of moving goods along them turns it into a regional or global political risk that causes "active participation of the international community". For example, internal migration of the population of Georgia in 2008 and Ukraine in 2014 violated the metastability of the two states and led to increased political risks. It became necessary to create new approaches to managing political risks not only in these states, but also at the regional and global levels [18].

A key feature of supply chain disruption risk management approaches is the transfer of political risk management to "international intermediaries". In fact, the more the supply channels have suffered, the more actively the "international community" influences the political leadership of the state. It independently assumes the functions of a third party and makes decisions not in the interests of the state, but in the interests of the established supply channels security. "International intermediaries" primarily protect investments and the interests of the citizens of their countries.

The third global force in determining and managing political risks is the technological revolution. The authoritative economic periodical Journal of Evolutionary Economics has published a series of articles that reveal the impact of the technological revolution on the prevailing business models. They aimed to discuss innovation cascades, which radically change the understanding of political, economic, social and scientific organizations (projects) on a year-by-year basis. J. Niosi and M. McKelvey explore innovation as sudden bursts of radical change that create the conditions for the next rapid wave [19].

Innovation cascades include a long series of interrelated radical innovations that can be traced through various scientific and technological indicators such as patents, publications, reports, instructions. Exploring the cascades of innovation that are driving the technological revolution provides the foresight and facilitates political risk management.

In the $21^{\text {st }}$ century, social media, cell phones and the Internet have transformed the political environment into online communication. Forty-eight percent of the world work and communicate online [14]. This figure is expected to reach at least 75 percent by 2030 .

New technologies lower the cost of collective action by helping like-minded people find each other and join the common case, even over great distances. Moreover, social activity has ceased to be a manifestation of civil society and social activists. New technologies provide hyperlinks that enable passersby to post videos from mobile phones that go viral. For example, on April 9, 2017, after United Airlines resold a flight to Louisville, Kentucky, the airline decided to remove four passengers. One of them, David Dao, refused to leave the plane. The passengers videotaped the moment when the security forces dragged Tao out of the plane, and posted the footage on Twitter and Facebook. Two days later, United Airlines shares lost $\$ 255$ million in shareholder value and analysts began to worry about the impact on the airline in the Chinese market. On social media, commentators began to argue that Tao was discriminated against because he was Asian [14].

Conclusions. Thus, we examined modern approaches to risk management and identified three global forces that determine political risks and manage them. Based on the materials reviewed, the authors developed a sequence of political risk management in the countries with economies in transition. The Risk Management Framework focuses on building four core competencies: identifying risks, assessing risks, mitigating the risks that cannot be eliminated, and creating responsiveness to risk management.

An important place in political risks management in the countries with economies in transition is determining the characteristics of their unstable socio-political situation.

In general, the following competencies define effective political risk management in the countries with economies in transition: 
1. Ability to carry out an objective analysis and assessment of risks associated with the peculiarities of political development.

2. Ability to predict the steps taken and decisions made by the legislative and executive authorities of the countries with economies in transition, which can affect the integrity and security of investments and supply chains.

3. Ability to develop documents (instructions, decrees, laws) that will ensure the implementation of the chosen strategy and tactics of risk management based on the specification of the socio-political situation of a country with the economy in transition.

4. Ability to use available methods and tools to study the feasibility of private investors and international organizations entering the market of countries with economies in transition.

5. Ability to develop a procedure for risk ranking based on the principle of acceptability, which allows for a highly accurate assessment of projects and investments that meet the objective interest of stakeholders.

6. Ability to create risk response capabilities that will ensure effective risk management, as well as continuous education and improvement in risk management.

\section{References.}

1. Hunziker, S. (2019). Enterprise Risk Management: Modern Approaches to Balancing Risk and Reward. Springer. https:// doi.org/10.1007/978-3-658-25357-8.

2. Lean Project Management (2020). Retrieved from https:// leanpm.org/manifesto-on-projects-and-project-management.

3. Filipchuk, V., Malkina, G., Kolyukh, V., \& Petrenko, I. (2020). Governance models in the globalization era: from moral to political responsibility. Naukovyi Visnyk Natsionalnoho Hirnychoho Universytetu, (3), 177-182. https://doi. org/10.33271/nvngu/2020-3/177.

4. The National Institute of Standards and Technology (NIST) (2020). Retrieved from https://www.nist.gov/.

5. Ost, L. (2019). NIST's Real Impact on Innovation and Quality of Life. Retrieved from https://www.nist.gov/featured-stories/nists-real-impact-innovation-and-quality-life.

6. Petrenko, I., Malkina, G., \& Kolyukh, V. (2019). Management features of modern think tanks. Scientific Naukovyi Visnyk Natsionalnoho Hirnychoho Universytetu, (2), 130-136. https://doi.org/10.29202/nvngu/2019-2/21.

7. Fatkhutdinov, V. (2020). The Pension Fund of Ukraine: Rethinking Risk Management during the Creation. Ukrainian Policymaker, 6, 15-23. https://doi.org/10.29202/up/6/2.

8. Kostenko, I. (2020). Current Problems and Challenges in International Space Law: Legal Aspects. Advanced Space Law, 5, 48-57. https://doi.org/10.29202/asl/2020/5/5.

9. Burke, R., \& Demirag, I. (2017). Risk transfer and stakeholder relationships in Public Private Partnerships. Accounting Forum, 41(1), 28-43. https://doi.org/10.1016/j.accfor.2016.06.004. 10. Prykhodko, A., \& Oksin, V. (2020). Corruption Factor as a Destabilizing Element of Development of the Space Industry. Advanced Space Law, 5, 71-82. https://doi.org/10.29202/ asl $/ 2020 / 5 / 7$.

11. Mozgin, W. (2018). Ukraine in a Geopolitical Game between the West and the Russian Federation. Ukrainian Policymaker, 3, 36-42. https://doi.org/10.29202/up/3/5.

12. Bazaluk, O., \& Blazhevych, T. (2016). The Image of an Ideal Ukrainian Politician. Ukrainian National Idea. Future Human Image, 6, 24-30.

13. Rudenko, S., Bazaluk, O., Tsvykh, V., \& Kalmuk, I. (2019). The Role of Philosophical Disciplines in Educational Strategies for Specialist Training in the Field of Public Administration. Naukovyi Visnyk Natsionalnoho Hirnychoho Universytetu, (3), 158-163. https://doi.org/10.29202/nvngu/2019-3/22.

14. Rice, C., \& Zegart, A. (2018). Managing $21^{\text {st }}$-Century Political Risk. Harvard Business Review, 130-138.
15. Możgin, W. (2020). The Perspectives of Human Freedom in a Post-pandemic Social Reality. Ukrainian Policymaker, 6, 63-73. https://doi.org/10.29202/up/6/7.

16. Svyrydenko, D., \& Stovpets, O. (2020). Cultural and Economic Strategies of Modern China: In Search of the Cooperation Models across the Global World. Future Human Image, 13, 102-112. https://doi.org/10.29202/fhi/13/11.

17. Benton, C.N., Napier, M., \& Ülkü, M. (2016). On Supply Chain Integration to Free Trade Zones: The Case of the United States of America. Global Business Review, 17(4), 779-789. https://doi.org/10.1177/0972150916645675.

18. Bazaluk, O., \& Balinchenko, S. (2020). Dynamic Coordination of Internal Displacement: Return and Integration Cases in Ukraine and Georgia. Sustainability, 12, 4123. https:// doi.org/10.3390/su12104123.

19. Niosi, J., \& McKelvey, M. (2018). Relating business model innovations and innovation cascades: the case of biotechnology. Journal of Evolutionary Economics, 28, 1081-1109. https://doi.org/10.1007/s00191-018-0561-9.

\section{Управління ризиками: підходи та сфери застосування}

\section{П. П. Шляхтун ${ }^{1}$, Я. А. Таран ${ }^{2}$, П. М. Олещук ${ }^{1}$, В. В. Колюх ${ }^{1}$, I. І. Петренко}

1 - Київський національний університет імені Тараса Шевченка, м. Київ, Україна, e-mail: polit-nauk@ukr.net 2 - Національний університет «Чернігівський колегіум» імені Т.Г Шевченка, м. Чернігів, Україна

Мета. Розкрити сучасні підходи управління політичними ризиками у країнах із перехідною економікою.

Методика. Автори використовували системноструктурний, структурно-функціональний метод, а також методи порівняння, аналізу, синтезу та експертної оцінки.

Результати. Автори розглянули сучасні підходи до управління ризиками та виокремили три глобальні сили, що визначають політичні ризики та управління ними:

1. Кардинальні зміни в політиці після закінчення холодної війни.

2. Інновації в каналах поставок.

3. Технічна революція.

На підставі розглянутого матеріалу автори розробили послідовність управління політичними ризиками у країнах із перехідною економікою.

Наукова новизна. Розроблена послідовність управління політичними ризиками у країнах із перехідною економікою на основі дослідження особливостей їх нестійкого соціально-політичного становища, а також глобальних сил, що визначають політичні ризики та управління ними.

Практична значимість. Використання результатів, отриманих при дослідженні особливостей управління ризиками у країнах із перехідною економікою, дозволяє виявити можливості процесу мінімізації негативних наслідків політичних ризиків та їх попередження для транзитивних країн, у тому числі й для збільшення їх інвестиційної привабливості з боку зарубіжних країн і міжнародних організацій.

Ключові слова: управління політичними ризиками, прийняття рішень, країни з перехідною економікою

\section{Управление рисками: подходы и области применения}

\author{
П. А. Шляхтун ${ }^{1}$, Я. А. Таран ${ }^{2}$, П. Н. Олешук ${ }^{1}$, \\ В. В. Колюх ${ }^{1}$ И. И. Петренко ${ }^{1}$
}


1 - Киевский национальный университет имени Тараса Шевченко, г. Киев, Украина, e-mail: polit-nauk@ukr. net

2 - Национальный университет «Черниговский коллегиум» имени Т.Г. Шевченко, г. Чернигов, Украина

Цель. Раскрыть современные подходы к управлению политическими рисками в странах с переходной экономикой.

Методика. Авторы использовали системно-структурный, структурно-функциональный метод, а также методы сравнения, анализа, синтеза и экспертной оценки.

Результаты. Авторы рассмотрели современные подходы к управлению рисками и выделили три глобальные силы, определяющие политические риски и управление ими:

1. Кардинальные изменения в политике после окончания холодной войны.

2. Инновации в каналах поставок.

3. Техническая революция.
На основе рассмотренного материала авторы разработали последовательность управления политическими рисками в странах с переходной экономикой.

Научная новизна. Разработана последовательность управления политическими рисками в странах с переходной экономикой на основе исследования особенностей их неустойчивого социально-политического положения, а также глобальных сил, которые определяют политические риски и управление ими.

Практическая значимость. Использование результатов, полученных при исследовании особенностей управления рисками в странах с переходной экономикой, позволяет выявить возможности процесса минимизации негативных последствий политических рисков и их предупреждение для транзитивных стран, в том числе и для увеличения их инвестиционной привлекательности со стороны зарубежных стран и международных организаций.

Ключевые слова: управление политическими рисками, принятие решений, страны с переходной экономикой

Recommended for publication by V.P. Horbatenko, Doctor of Political Sciences. The manuscript was submitted 11.05.20. 